\title{
From Secular Muslim Feminisim to Islamic Feminism(s) and New Generation Islamic Feminists in Egypt, Iran and Turkey
}

\author{
Zeynep Banu Dalaman ${ }^{1}$
}

\begin{abstract}
In dominantly Muslim societies, there bave been two major feminist paradigms referred to as "secular Muslim feminism" emerging at late nineteenth century and "Islamic feminism(s)" arising after the 4th women world congress in Beijing in 1995. They evolved in historical contexts where new subjects and identities were being re/fashioned out of shifting combinations of religious, class, ethnic, and national affiliations. On the one hand, secular Muslim feminism joined the western oriented first wave of liberal feminism including secular nationalists, Islamic modernists, humanitarian/ human rightists, and democrats. Islamic feminism, on the other hand, is expressed in a single or dominantly religiously grounded discourse taking the Qur'an as its core text. In this article, I reflect on the roots of feminism in the Middle East with a particular emphasis on Egypt, Iran and Turkey. I discuss secular feminism and Islamic feminism, and what makes them distinct. Finally, I discuss whether a new wave of Islamic feminism has been formed with the criticisms of a new generation of Islamic feminists.
\end{abstract}

Keywords: Islamic feminism; secular Muslim feminism; intersectionality; new generation Islamist feminists

Interpreting Islamic women's organizations with a Western approach has always been the most common mistake, which in the end disregards the influence of Islam and the role of the state in studies on women living in Muslim states (Kandiyoti, 1997). Furthermore, Western feminists ignore the experiences and struggles of women in these countries. Muslim women are described as "misty eyes looking behind burqas"; yet it is never understood that the problem is never the burqa, but the women's rights in public sphere. Thus, women's real problems are not taken into consideration. Women need to be considered and understood as individuals, rather than discussing women's movements as a non-existing religion or a culture in Islamic states. Thus, in order to better understand the feminist movement, how these women are being organized and what issues they are attempting to address ought to be examined.

It would be appropriate to point out a confusion that arises in the evaluations about women living in Muslim societies. From a Western perspective, "Muslim woman" refers to all women, whether they are secular or religious living in a Muslim society. However, it is necessary to distinguish between women who see religion as the essential element of their identity and those who have adopted a secular worldview. In other words, it is necessary to reveal the difference between a woman who has made Islam a part of her daily life and pursuing a life

${ }^{1}$ Zeynep Banu Dalaman, Istanbul Ayvansaray University, Department of Political Science and International Relations, İstanbul, Turkey.E-mail: banudalaman@ayvansaray.edu.tr 
accordingly, which can be seen as "pious woman", and a woman who has chosen a secular lifestyle, a "secular Muslim woman". There is also a group of women who politicize Islam, referred as "Islamist women". This women's group was excluded from this study because it is purely political and has no connection with feminist discourse. Secular Muslim women, in general, defend the values and discourses of mainstream feminism and argue for the incompatibility of Islam and feminism, thus this group of women can be called "secular Muslim feminists". On the other hand, those pious Muslim women who endeavour to establish a new discourse by trying to establish a link between Islam and feminism, while at the same time living according to Islamic values and rules, are "Islamic feminists". Amina Wadud is the first to use the term "Muslim Secular feminist" and "Islamic feminism" to defend the divide between two. Against this context, the main purpose of this study is to examine whether Islamic feminism can be separated from mainstream feminism, and whether the next generation of Islamic feminists, who criticize earlier Islamic feminists, can develop a new discourse and create a new wave. To this end, firstly, main differences between secular Muslim feminists and Islamic feminists will be highlighted. This will be followed by an extensive overview of the formation, discourse and intergenerational differences of Islamic feminist women. Finally, we will discuss Islamic feminism within the current feminism debates.

\section{Muslim Secular Feminism vs Islamic Feminism: An Historical Perspective}

The emergence of feminism in the Islamic geography occurred concurrently with the West, especially in the contexts of the Ottoman Empire (Turkey), Egypt and Iran. The first wave of feminism in the West was shaped once women had realized that they were part of an oppressed group; while in Islamic geography, the determining factors were nation-state, nationalism and rationalization struggles at late 1800s and the beginning of 1900s. In the Islamic World, the first woman organizations were established by the upper class women with high levels of literacy; while in the West, specifically in the United States, France, Germany and England, the feminists mostly came from the middle class and working class backgrounds and fought for women's right to education, right to vote and equal pay. In the Ottoman context, however, women held a symbolic role and image at the core of the modernization process, and their activities were state-mandated (Çaha, 2010; 413). A major problem of the women's movement was its limited connection with ordinary women who composed the bulk of the society. Accordingly, women's organizations were not regarded as representing their interests. Other social changes had to take place before improvements in women's rights could be observed (Graham-Brown, 2001).

At the beginning of the 1900s, women's movement in the Islamic geography, especially in the Ottoman Empire, Egypt and Iran, was at a critical junction whereby, mostly due to the Western influence, women living in Muslim societies had begun to question their rights. In the later 19th century, educated women in the Ottoman Empire, Egypt and Iran started to take action and began to voice their concerns. Debates on women's problems, in which men were also getting involved, started in the Middle East concurrently with the women's movements in the rest of the world (Bora, 2010: 53). Women magazines of the period were playing the major role in spreading the word and slowly forging this movement at late Ottoman period. There were around forty magazines where women could express themselves individually, discuss their problems and stand up for their rights against the existing Islamic sanctions and patriarchal social codes. Women's organizations in Islamic geography, on the

Border Crossing 
other hand, formed only after the 1990s and took on a new dimension with the Second Wave of feminism that had emerged in Europe in 1970s.

After the First Wave, during which women had gained the right to vote during, feminism subsided into silence in many countries during the years of Second World War and the aftermath. Simone de Beauvoir, in her book The Second Sex (1949), however, voiced from an existentialist perspective how women were marginalized. She also advocated that women had to have a profession and gain access to public life. The debates during the second wave of feminism have focused on the patriarchal structure as the main reason for women's problems and defended that women are being oppressed by men. The topics such as abortion, violence and harassment have been at the centre of the Second Wave. The impact of the Second Wave of feminism reached the Islamic geography in the 1980s, about 15-20 years later than the West. With the advent of identity feminism - akin to the Black feminism that emerged in the United States - Islamic feminism began to be discussed in Muslim-majority countries.

In a nutshell, Islamic feminism is a women-centred reinterpretation of major Islamic resources such as the Quran and the Hadith. Islamic feminism was influenced by the existentialist philosophy and the postmodern approach coming from the West. Muslim philosopher Fazlur Rahman and his modernist approach has also impressed this movement and encouraged people to be activists (Çaha, 2010: 347). On the other hand, there are also some incidents of women's movements in the very early ages of Islam, when a male-dominated system prevailed in the public life. "Harlots of Hadramaut" incident is the most remarkable revolt in the name of freedom by Muslim women in Islamic history. Some Arabic sources state that a group of tribe women living in Hadramaut (a region in east Yemen) in the eleventh year of hejira rejoiced at the Prophet Muhammad's death and celebrated it. They claimed that women used to have equal standards and rights with men before Muhammad, yet with the rise of Islam, they contended, women were excluded from all workplaces and forced to cover themselves. Thus, claiming that their freedom and equal rights came to an end with Muhammed, Hadramaut women rejoiced at Muhammad's death because, they believed, the unequal system would be over. However, the Hadramaut women and people who watched their celebration were killed, and those who killed them were commemorated as "merit holders" (Arsel, 1989: 467-471).

Divergent interpretations of the sources of Islam have yielded different points of view and practices in countries governed by the Islamic law, Sharia. For example, prominent Muslim philosophers of 1970s, Fazlur Rahman, Ali Shariati, Mevdudi, Mutahharri have different interpretations on women and family issues. According Ali Shariati, Islam and Islamic tradition require women to cover themselves. He regards Fatima as the ideal Muslim woman representing Islam and as a religious symbol. Shariati claims that Fatima is believed to play a political role as a protector and proselytizer of Islamic ideology and represents the ideal women with her personality and talents, rather than fashion clothes, make-up and jewellery (1986). Fazlur Rahman, in contrast, advocates chasteness and honesty for women, rather than isolation and segregation (Sancar, 2016: 174). Nevertheless, women in most of the Islamic geography are oppressed by the rule of men. To underline this, the Somali-born-Dutch woman activist Aayan Hirshi Ali objected to the world-famous activist Eve Ensler who used to start every speech by saying "pressure on women is the same all around the world" (1995 and uttered "Eve Ensler does not know the rules of Sharia and how it oppresses women" (2000). 
Even though Islamic feminism goes a long way back as a movement, the term Islamic feminism was used for the first time in 1992 in Tehran, in a woman magazine called Zanan (Women) edited by Shahla Sherkat (Kaya, 2018). In Europe, the term was started to be used at the beginning of the 2000s. Islamic feminists defend that Islam was formed by maledominated thinkers that treat women unequal to men and that Islam has to be free of female exclusion, (İngün, 2005: 109). She defends that instead of fighting for gender equality and women empowerment, the Quran needs to be revised by taking women's issues into consideration (Wadud, 1999). In fact, her book Quran and Woman: Rereading the Sacred Text from a Woman's Perspective (1990) is a reinterpretation of the Quran from a female perspective. Wadud's main concern was to bring the female voice in the Quran out of the shadows and to eliminate all expositions in favour of men. Islamic feminists argue that Islam has risen in a male-dominant culture where women were already oppressed, and that the Quran was revealed to reorder this corrupted system. Thus, rearrangements for women's activities in public spaces and equal representation in public are suggested. This feminist point of view suggests that the Quran and the Hadiths should be reinterpreted. Such a new interpretation of the Quran from woman's perspective has opened up discussions as to how Sharia laws could be implemented regarding new issues (Tohidi, 2003). Islamic feminists rely on a key principle of the Quran, that "all human beings are equal". They claim that gender inequality is a result of the Arab world's patriarchal cultural system. In other words, Islamic feminists argue that the principle of equality, taught and exemplified in the Quran, was customized for the male-dominant culture in Arab countries before Islam; and therefore, they defend that the Quran must be reread and reinterpreted from this perspective (Badran, 2002). Some scholars, however, argue that the new discussions that the reinterpretation of the Quran has created conflict with the Sharia laws and have changed their implementation (Moghadam, 2002: 1147).

\section{Muslim Secular Feminism and Islamic Feminism Divide}

Around 1980s, religious feminism emerged among Muslim women under the name of reform. This movement has mainly risen in big cities, among reformist and educated religious women, for whom protecting their Islamic identity was a major concern and thus religion was a dominant element of their morals and traditions. Various factors played a role in the rise of Islamic feminism, such as discussions on gender equality, family life and the concept of social gender interpreted with a feminist perspective, as well as rising migration due to globalization and the resulting acculturation. Furthermore, the developments in mass communication raised the awareness of women in Muslim countries (especially in Egypt and Iran) and encouraged them address to their inner conflicts between traditional and modern interpretations.

Islamic feminists claimed that the Quran gives women freedom of legal citizenship and right to work apart from their descriptive roles. Women's Organization of Islamic Revolution, founded in 1979 in Iran, was one of the most influential organizations, criticizing the government for twisting the verses of the Quran to oppress women. They also uttered that, akin to women's sexual objectification in the West, the Revolution was also objectifying women through being covered. Especially after the 1980s, there has been an improvement in women's press in parallel with the pressure on women. Various magazines, such as Zanan, Women's Rights, Women's Message, The Call, and Hagar's Message made a tremendous impact during this period. The common statement of these magazines is that gender

\section{Border Crossing}


discrimination has increased to a high level after the "Islamization of society," and that women's status in family needs to be improved.

This generation's Islamic feminist movement in Iran, led by Afsaneh Najmabadi, has been described as one of the rarest movement that bridges the divide between religious and secular feminists. This position was explicitly articulated by Najmabadi in an article published in Zanan, stating that she was open to the influences of Western feminists. On the other hand, other authors of Zanan referred directly to the Quran in their writings, which fundamentally forms the magazine's outline. Thus, Zanan has become a platform in which the secular feminist movement and Islamic feminist movement are being synthesized (Yüce Tar, 2013: 83-87), suggesting that there is common ground between the Iranian women's movement and the secular feminist movement in their fight to improve their social status. Mir-Hosseini presented a detailed analysis of the writings of Zanan and pointed out that the unexpected outcome of the Iranian Revolution had been raising the society's gender consciousness. Thus, the controversies over the Islamic family law, alimony and children have created a new opposition; and the inability of the Islamic Republic of Iran to ameliorate women's status triggered women's organizations and has raised awareness of Islamic feminism. Particularly, authors such as Shekart, Behrouzi, Groji, Sa'dizadeh took a stand against the laws that ignore women and confine women in a proper sphere (Güç, 2008: 661). Two academic thinkers were using the term Islamic feminism at the end of 1990s that many Muslim women referred to: Margot Badran (1996) and Ziba Mir-Hussesin (1996). Sociologist Nilüfer Göle, in her research book The Forbidden Modern, used the term Islamic feminism to describe a new feminist discourse emerging in Turkey (1996). In this study, she mentions that Muslim female figures that combine the traditional values of Islam with the universal values of modernity will emerge. By the mid-1990s, there was growing evidence of Islamic feminism as a term created and circulated by Muslims (Badran, 2002).

The notion of Islamic feminism, which emerged in the 1990s, has not only opened up new fields of activities for feminist readings and activism, but also given rise to variety of debates about 'different feminisms'. Notably, the very concept of Islamic feminism has been a controversial issue for combining two notions that seem to be in contradiction - Islam and Feminism. The term has been heatedly debated and both feminists and Muslims have rejected it as two fundamentally incompatible ideas. In particular, radical feminists of the Second Wave hold that the term 'Islamic feminism' is oximoron. Secular Muslim feminists reject it because they argue religion, in general and Islam, in particular, oppress women (Moghadam, 2002). Many Muslim women also reject it because they feel 'feminism' is a secular invention imposed on them from outside, from the West. For example, Tunisian lawyer and activist Neila Driss claims that 'Islam' and 'Feminism' are contradictory notions that cannot coexist. She says,

"Feminism and Islamism cannot exist together; there cannot be Islamic feminism. These two notions are contradicting. If a woman is Islamic, it means that she accepts dependency on men and agrees with whatever they say. It is impossible that these women can compromise with notions inherent in feminism, such as equality and freedom. Those who believe they are compromised are living in a fancy lie." (2018)

A second-wave feminist from Turkey, Tülin Tankut, also objects to the notion of Islamic feminism based on similar reasons (2019). An Iranian Islamic feminist Ziba Mir-Hosseini, for instance, claims that Western norms, revealed through feminism, came to an end and that it 
is not possible to take women's movement forward with a unilateral aspect "Secular feminism in the Muslim world", she states, "served its purpose by clearing the path for women's rights in politics and society. Unfortunately, this perspective has no more advantages to give us, Muslim feminists" (Mir-Hosseini, 2006: 644). By the same token, Pakistani origin, BritishAustralian scholar Sara Ahmed rejects the idea that feminism travelled from West to East, and argues that this conviction is an outcome of the Orientalist perspective and that the premise of this thought was not determined (Ahmed, 2016: 16). Nevertheless, Ahmed indicates that her feminism journey was developed through her relationship with her aunts which lives in Pakistani.

\section{First Wave of Islamic Feminists}

There are two critical turning points that activate Islamist feminists and highlight their difference form Muslim Secular feminists. First breaking point was the Beijing conference in 1995, and second one was the use of intersectionality within the feminist methodology. In 1995 in Beijing, the 4th Women Conference hosted 30.000 women activists form all around the world. It was the largest conference of women where Muslim women also participated in large. "Sisters in Islam" is a Malaysian faith-based human rights organization founded in 1989 and was represented by Amina Wadoud. Wadoud (2020) explains the awareness she experienced as an Islamic feminist in Beijing as follows:

"When we participated in Beijing to represent South East Asian [SEA] Muslim women, we exposed key factors of our localizations South Eastern Asian Muslim women. Most Muslim women in SEA identify themselves with their faith unlike women you can find after post-Muslim era in Middle East and North Africa [MENA] region, Asia with Muslim population, like in Turkey. Secondly, Muslim women in SEA have greater peace with their Muslim identity. They have serious concerns and object to patriarchal and hegemonic comment made in the name Islam. These women assert their identity as Islamic and objection to patriarchy. At Beijing, very few people were using the term Islamic Feminism."

According to Amina Wadoud, two major discursive divide were discussed on gender and Islam at Beijing: Secular Muslim Feminism and western Liberal Feminism, which is the mother idea of feminism. She criticizes that localizations and problems of different women were not even mentioned during the conference; rather the debates were based on the problems of the white, upper class, educated women of global north. In other words, she claims that despite good and measuring features of feminism, localization was not taken into account. Thus, it was not universal according to Amina Wadud (Wadud, 2020).

Amina Wadud rejected the conclusion statement of the Beijing conference (UN Beijing Full Report, 1996) which, according to her, was representing the view of Muslim Secular Women (Wadud, 2020):

"We have to remove religion from the discussion of women's rights. We cannot have both feminism and Islam or both human rights and Islam. We call Muslim women who have accepted this statement as "Muslim Secular Women".

Islamic women also reject to be referred to as "Islamist Women", who present their discourse in the context of political Islam, and regard Islam as conceived dialectically opposing to any 
agenda set by the West, UN and CEDAW. ${ }^{2}$ Wadud claims, that they perceive patriarchy as secret or divine, thus, patriarchy and men's way of knowing is uninterrogated. Both Islamist women and secular Muslim women have interpreted Islam and Feminism in a patriarchal manner, according to Amina Wadud.

Second breaking point is the exclusion of Muslim identity from "intersectionality" definition. Kimberlé Williams Crenshaw (1989) is known for the introduction and development of intersectionality, the theory of how overlapping or intersecting social identities, particularly minority identities, relate to systems and structures of oppression, domination, or discrimination. Yet when she coined this term thirty years ago, she did not mention religion as one of the factors of intersectionality. Islamic feminists, however, define feminism by taking into account the localization of Muslim women. While rejecting the definition of both Islam or feminism, they see their differences emanating from their localizations; and this is a part of intersectionality of feminism according to them. Wadud (2020) states this as follows:

"Feminism means women are whole human beings. All humans are equal. Women do not need the prevention of men to be equal. Women would have rented all dignity and equality by Allah at the time of our creation. The purpose of the creation is to be caliphate, a moral agent of Allah. There is a consensus that Islam in just classical times, justice was understood in the context of equitable distribution and equitable differences. Justice must include equality. Equality is not sameness, it is however, is dignity with our distant localizations, realities and our differences."

They say that Islam is built up on fundamental monotheist principles called "Tavhid" (oneness):

"Tavhidic (monotheist) paradigm requires faith to Allah, and this requires dignity and equality between all human beings in horizontal and reciprocal way. The monotheist paradigm is the base of social justice and also the cornerstone of Islamic feminism. Islam is a way of life which requires full humanity for women or it requires feminism. Using feminist methodology is central." (Wadud, 2020)

Thus, Islamic feminism takes into consideration the context of Muslim women's everyday life. The principle rule is to understand sacred texts and puts context over context. From the intersectional perspective of feminism, utilizing different religions and ethnic origins, it can be said that Islamic feminism can also open up new opportunities for itself.

Islamist feminists organized their first international congress in October 2005 and assembled over 400 delegates in Barcelona. The priority of the Congress was to initiate collaboration between Muslim women and the global feminist movement, and to promote the emergent movement of Muslim women for human rights. 400 participants from 20 countries attended these congresses - interestingly that there was no participant from Turkey (Gürhan, 2010: 379, Yüce Tar, 2013: 87). During the course of the meeting, it became clear that Islamic feminism was a reality in many countries with a Muslim-majority population. The Congress heard from women fighting for their rights and working in very difficult conditions against the implementation, in the name of Islam, of highly sexist and discriminatory family codes of

2 The Convention on the Elimination of all Forms of Discrimination Against Women (CEDAW) is an international treaty adopted in 1979 by the United Nations General Assembly. Described as an international bill of rights for women, it was instituted on 3 September 1981 and has been ratified by 189 states. 
behaviour. After the October 2005 congress, second and third International Islamic Feminism congresses were held in November 2006 and October 2008, with considerable impact on feminist movements in the Muslim territories. At the first congress, it was suggested that the Quran had to be carefully examined and interpreted as granting equal rights; also a call for jihad for women's rights was made. At the second congress, the topics of Sharia, family, Islam and social gender inequality were discussed. The concluding statement of the last Islamic Feminism Congress touched on the most important distinctive feature of Islamic feminism: "The regulations referred to as Islamic laws are not the laws of Allah. They are the laws created by people hundreds of years ago in societies, where women were seen as the property of men and religious discourses were entirely in the hands of men" (Women's UN Report Network, 2006). At the fourth congress, held in 2010, the relationship between Sufism and feminism was discussed, and the works of the Islamic women's organizations for women's rights have been moved to an international level with the intension of improving the status of Islamic feminism.

Musawah ('equality' in Arabic) is the biggest organization led by Islamic feminists "seeking to reclaim Islam and the Koran for themselves", applying progressive interpretations of sacred texts usually referred as feminist tafsir. This global movement for equality and justice was launched in February 2009 at a global meeting in Kuala Lumpur, Malaysia, attended by over 250 people from 47 countries. It is composed of NGOs, activists, scholars, legal practitioners, policy makers, and grassroots women and men from around the world. Launched 20 years after Sister in Islam, Musawah can be considered as a continuation of it. The vision Musawah is a world where the basis for all human relations is equality, non-discrimination, justice, dignity. Musawah defends that equality and justice in the Muslim family is both necessary and possible, and work for the advancement of human rights for women in Muslim contexts, in both their public and private lives (Musawah Official Website). They aim to bring new vision to intersectionality of feminism and include İslamic feminism in its definition.

In Turkey, the ground of opportunity developed in the 1980s as a result of liberal politics for religious groups. New associations were built and new journals were begun to be published by religious women's groups. A change was observed in the values of religious groups with strong emphasis on education of female children. The demand of pious female students to attend universities with their headscarves on, however, faced the reaction of the Kemalist elite who conceived it as a revolt against secularism and modernization. The ban on headscarves at universities and the reactions of religious groups raised the cleavage between Kemalists and religious groups over the headscarf (Çaha, 2010: 121). The first wave of Islamic feminist in Turkey, thus, struggled to take part in the public life with their headscarves in the 1990s. Their understanding of public life was similar to that of feminists, and they reacted to the traditional roles ascribed to women claiming that these roles were shaped by the patriarchal culture rather than the values of Islam. Thus, in order to change the traditional roles and develop an egalitarian understanding of Islam, some of them argued that they had to re-interpret the religious texts from women's perspective. They also criticized an essentialist understanding of women, pointing out that women are oppressed in different contexts and that as Muslim women they have a different identity, different context of inferiority and different experience, which, they stressed on, had to be taken into account by feminists. Most of the first wave Islamic feminists that has frequently been shown as an authority in debates on Islamic feminism in Turkey have been organized around Ankara Capital City Women's Platform. One of the founders of the Platform, Zehra Reçber, utters that they do not fully reject feminism yet 
have their own way of defining it, as she says: "Our feminism is a self-appointed feminism, we do not believe that we have to accept the entire feminist discourse" (Çaha, 2011: 128).

\section{Towards a Second Wave of Islamic Feminism}

Islamic feminism has a social movement dimension, thus can be considered within the women's movement; yet it also is in the theological field. Islamic feminism has been discussed both in the theological field and within feminism since the 1990s. Islamic feminists distance themselves from the mainstream feminist movement because of their religious identities. They argue that the feminist movement is marginalizing itself and is not even considering religion as a dimension in the interpretation of the intersectionality of feminism. In fact, while Islamic feminism stands against the first and second waves feminism which demand women's rights and question women's identity, and criticizes the representation of these waves by a certain class of women. Islamic feminism is located in the middle of the different feminisms that are defined by the intersection of different identities questioned by the third wave. Asma Barlas (2005), both an Islamic feminist and a Pakistani-American writer and academic, refuses to use the word "feminism", but she use feminist methodology. She questions whether the conflict that Islamic feminists have with feminism is with their own multiple identities. Asma Barlas, while questioning this multiple identities, refers to the colonial memory in Pakistan and states that feminism is a part of imperialist feminism (2002).

Aysha Hidayatullah (2014), an associate professor of Islamic studies, on the other hand, argues in her writings that the Quran and hadith interpretations are under the monopoly of men and that the main aim of Islamic feminism is to break up this monopoly and male centrism. The idea that there are many verses highlighting equality of woman and man is one of the theological debates of Islamic feminism.

As a male Islamic reformist and philosopher Mohsem Kadivar (2006) emphasizes in his book on women and Islam that especially the ulema who read and interpret Aristotle revealed the distinction between men and women, and that this distinction is not correct in today's socioeconomic situations. Muslim scholars, following Aristotle, construed justice as deserts-based on the basis of proportional equality, and considered women as entitled to fewer rights because of what they considered to be women's inherent lesser capacity. They took the first type of verses and hadith as the basis for equal rights, and the second type as the standard for women's rights and duties, and defended patriarchy as consistent with justice and Shari 'a. The oldest and most common concept of justice, which is accepted by Muslims to be compatible with the Quran and Islam, is close to Aristotle's concept of distributive justice. Accordingly, the definition of justice, in which everything is placed where it belongs and accordingly, everyone is given the right as much as they deserve, reflects the understanding of justice by Muslim philosophers, based on the Aristotelian concept that supports inequality stemming from slavery and gender.

Aziza al-Hibri argues that, according to the taehvid paradigm, thinking that men are superior to women is a situation that conflicts with the unity of God. Equality and justice are emphasized in this paradigm (1982).

Amina Wadud also says that in feminist methodology, sharia and figh (Islamic law) should be separated. While sharia (muslim canonical law)is the revelation of Allah, figh is an effort of people to understand and will always be incomplete because it is a human interpretation. It is 
very difficult to detach from biased personal comments. Islamic feminists say that by speaking in the name of Allah (God), men actually impose their own patriarchal interpretation (1999).

A prominent scholar on Islamic studies, Ayesha S. Chaudhry, demonstrated how the patriarchal nature of the pre-colonial Islamic tradition creates problems for contemporary Muslims who seek to create a gender egalitarian vision of Islam (2014). Since they cannot anchor their egalitarian vision of Islam in the authority granted by the "Islamic tradition", their authoritative claims are weakened. Thus, they run into what she calls the "egalitarianauthoritative dilemma", wherein a gender-egalitarian vision of Islam must find a way to root itself in the Islamic tradition even while departing from core values of that tradition — namely patriarchy (Chaudhry, 2013).

The only thing that Islamic feminists want is to interpret the verses with a holistic point of view in accordance with daily life in today's conditions. While making these comments, they expect the content of international conventions on women's rights and human rights to be included in these comments.

\section{How do the new generation of Islamic feminists criticize the previous generation?}

First generation Islamic feminist scholars, such as Aysha Hibayatullah and Ayesha Chaudry form a theology based on equality verses. But the new generation of Islamic feminists refer to hierarchy verses that cannot be explained in context. They especially question the punishment of women for disobedience in the $34^{\text {th }}$ verse of Surah Nisa ${ }^{3}$ and how to interpret the verses containing psychological and physical violence against women. Older generations say that questioning this verse droves pious Muslim women into an impasse. Talking about the necessity of reform on these verses, they argue that a faith-based rejection is needed.

Family law is actually one of the most important common problems that Islamic feminists face, they talk about the need to find national solutions based on the localization of feminism formula. Here it is useful to divide the countries with Muslim populations into three according to their legal structures. Completely secular and the rule of law recognized by countries such as Turkey, countries that are completely governed by sharia such as Iran, Sudan, Saudi Arabia and many countries in the MENA region such as Egypt are countries that regulate family law according to religious references within the secular law structure.

Different practices in different countries constitute the most discussed topics by Islamic feminists in this sense. Men's right to polygamy, the age of marriage of young girls and the reserve set in Article 16 of the CEDAW that says" States shall ensure that women have equal rights with men in relation to marriage and as parents, as well as in respect of other aspects of family life." (UN Convention, 2006). The reasons for putting this reserve claim that this clause breaks the unity and integrity of the family, Islamic feminists struggle for the break of this reserve locally, because this clause gives a full equality that Islamist feminists fight for. The

\footnotetext{
${ }^{3}$ Nisa Surah, 34th verse: "Men are the caretakers of women, as men have been provisioned by Allah over women and tasked with supporting them financially. And righteous women are devoutly obedient and, when alone, protective of what Allah has entrusted them with.1 And if you sense ill-conduct from your women, advise them 'first', 'if they persist," do not share their beds, 'but if they still persist," then discipline them 'gently'.2 But if they change their ways, do not be unjust to them. Surely Allah is Most High, All-Great."

Dr. Mustafa Khattab, the Clear Quran (https://quran.com/4)
} 
biggest problem of new generation Islamic feminists is the awareness raising of women about their rights.

Marwa Sharafeldin, one of the new generation Islamic feminists in Egypt, who also works jointly with the Musava movement, contributes to many international conferences in order change of family law in Egypt. In one of her speech, she states: as a Muslim family law reformer:

"I think that Islamic feminism is actually going to be the entry point for this whole renewal of Islamic discourse... So it will be up to the Muslim women themselves who are not willing to let go of their religion, but at the same time, they are not willing to accept being treated as second class citizens because of a certain version of religion." (America Abroad Media)

Omaima Abou-Bakr, one of the important names for new generation Egyptian Islamist feminist, is among the founders of the "Women and Memory Forum" that step up their work after the Arab spring period (VMF). They held the first Islamic feminism conference of Egypt in 2011 and discussed the issue of changing family law. This organization was criticized both for inviting to the conference Shaykh Jamāl Qutb, the former Chairman of the Azhar's Fatwa Committee as one of the al-Azhar scholars and giving him the last word. Abou-bakr participated gender lessons that were given to the Ulama, she initiated the discussion around 34 th verse of Surab Nisa, which is the most controversial surah for women in Islamic theology. This verse is the clearest Qur'anic example of hierarchy between men and women. It presents numerous difficulties for translation, since so many of the words have contested meanings. When the Musawah movement moved its secretary general to Egypt in 2012, the new generation of Islamic feminists grew stronger and encouraged deeper discussions. The new generation of Islamic feminists do not hesitate to touch on taboo subjects. One of the critical debate was one marital rape, which is not considered as a crime in Egypt. According to the World Health Organization (WHO), sexual violence includes marital rape, and is defined as physically forced or otherwise coerced penetration of the vulva or anus, using a penis, other body parts or an object. The 2017 records of Family Courts show that 60 percent of Egyptian women were subjected to marital rape, while 10,000 complained of sexual violence. While Article 267 of the Penal Code criminalizes rape, the law does not protect a woman from marital rape. "Marital rape isn't recognized in the Penal Code due to the fact that the government believes that as long as the married couple holds a legal document that proves their marriage, then it's essentially a consensual relationship, not rape." (Mohamed, 2017)

Musawah in Egpyt continues to organize webinars, panels to discuss the issue and Muslim family law reform (Musawah, 2020).

In Turkey, independent from the mainstream feminism and Islamist women's movement, Islamic feminists questioning their Muslim identity, established new platforms. In Turkey, these feminists first gathered under "Women Against Violence Muslim Initiative" in 2012, second under the umbrella of the first online Muslim women's portal Reçel-blog in 2014 (Recel-blog).

In 2013 Gezi Park protests has been little reflection on contemporary Islamic feminist thinking in Turkey. Dorroll argues that one important political and intellectual legacy of the Gezi movement has been the development of certain intersectional discourses in Islamic 
feminism in Turkey. The shared experience of marginalization felt by pious Muslims, women, ethnic and religious minorities, and the LGBTIQ community has begun to broaden and complicate the scope of Islamic feminist discussions of liberation and social justice (2016). The first Islamic feminist organization Havle Women's Association has become operational in 2018 by the co-works of these initiatives and defines it self as the first "Muslim feminist association" in Turkey. The association, whose main aim is to increase the participation of Muslim women in the feminist movement, thinks that this participation can be possible by making diversity and differences visible (Havle Women Association's Blog, 2020). Havle Women's Association was established with the aim of identifying and combating the difficulties and obstacles faced by women, and especially women who identify themselves as Muslim, in all areas of life. The primary way to achieve this is to address the problems faced by Muslim women in mosques, which have specific problems, and discriminatory expressions and approaches to their choice of covering their heads or not. The second is to discuss and eliminate the claim that problems such as early and forced marriages are Islamic (Dalaman, 2020: 247). This new generation Islamist feminist criticize the previous generation of Islamic feminist for joining the ruling party's patriarchal rhetoric and attitude towards LBGTI individuals.

Intersectionality is an important aspect of feminism in that every group must be represented, advocated for and carried along to the battlefield for new generation of Islamist feminists. Khadija Yusra Sanusiou, sub-edior of a magazine called the Republic, blogger for MTVShuga and the President of Yashafeni, a platform for social awareness campaigns against vices in Northern Nigeria, writes about Islamic feminism. She talks about the importance of intersectionality in her writings and expresses herself as "You can't call yourself a feminist, claiming to advocate for women's rights but excluding the LGBTQ+ community and identifying with institutions that are primarily patriarchal - a category many religions around the world subscribe to. Feminism is a 'one size fits all' t-shirt that cannot be reshaped to align with one's religious beliefs. But intersectionality-being inclusive of sexualities and accepting sex work as a respectable occupation-is not in accordance with Islam, which criminalizes acts of homosexuality, adultery and prostitution. Thus, feminism cannot work within the Islamic framework because it advocates for certain groups of people which Islam admonishes." (2020)

\section{Conclusion}

Feminist movements are subsets of women's movements, which, in turn, is a subset of social movements. Women's movements can be formed around various points of view as women collaborate to make public claims based on their female identities. In other words, not all women's movements have to be feminist movements. Social movements, and especially women's movements, in general, aim at social transformations; yet they usually have some form of legal and political concerns as well, such as recognition, participation, representation and empowerment. Global social movements such as \#Me'Too and \#HeforShe create new movement areas for women and also involve men in the fight against gender discrimination. Islamic feminist movement, on the other hand, is trying to create a new gender model with a new conceptualization of women-centered Islamism. It is worth pointing out that Islamic feminist movements should also be considered as women's movements, in which different approaches have emerged based on Islamic feminists' socio-political status, activities and the environments they live in. Yet it is crucial to recognize that in all these quests, feminism aims at ensuring justice and equality for women. Thus scholars underline that fields should be 
created in which various feminisms and voices who share the same aim can work together. British scholar and activist Sara Ahmed, for example, states that "feminism is a collective political movement for women" (Ahmed, 2016:10). Likewise, according to Badran, a scholaractivist and specialist in gender studies in the Middle East, secular and Islamic statements cannot be separated; therefore, attention should be paid to the interdependency of religious and secular feminism (2013). Wadud also considers Islamic thought as a solid basis of women in Quranic interpretation and uses traditional Islamic methods together with new social science tools (Wadud, 1999). However, compared to the Western feminist movement, the Islamic feminist movement is quite limited in practice as well as in theory. As Shahrzad Mojab states, Islamic feminism bears a resemblance to liberalism and positivism in theory. When it comes to practicing liberalism, it diverges from the West for not being enthusiastic and ambitious enough to desiring universal formal equality (2001).

From an Orientalist point of view, the notion "Muslim woman" stands for all women without any secular, religious, İslamic, feminist discrimination. This explanation is culturally acceptable; however, it does not explain the differences between a woman who puts religion at the center of her life and a woman who prefers a secular lifestyle.

The main issues of feminism today are unequal sharing of housework, domestic violence, wage inequality, low representation of women in politics, commercialization of the female body, violence against women, rape, harassment. All these problems deeply affect the daily lives of women and bring them together. The implications of these issues reveal how urgent it is for feminism to evolve into "a feminism without borders" that takes social and racial issues while criticizing male domination. Feminism can be strengthened by recognizing that there is more than one way to be a feminist and the legitimacy of alternative feminist discourses that express and take shape in different sources - whether religion, different political origins and traditions. When we consider the subject from the dimensions of understanding different feminisms and the localization of feminism, generation differences and these differences are not defined as a new wave will be unnecessary. A new generation of Islamic feminists has emerged, the mothers of these feminists were perhaps the first women to receive education and ponder the relationship between Islam and feminism. They represent a generation that is more educated, more questioning, more courageous, and more in touch with both the global north and the global south with the possibilities of digital technology than their mothers. Should we take them as the second wave of Islamic feminism or as part of the different feminisms that the fourth wave of mainstream feminism is talking about? Actually, our answer is both.

\section{References}

Ahmed, S. (2016). Living a Feminist Life. Durham: Duke University Press.

Al-Hibri, A. Y. (1982). Women and Islam.

Ali, A. H. (2008). AHA Foundation - New York, http://www.theahafoundation.org

America Abroad Media (n.d.). https://www.americaabroadmedia.org/radio/understanding-islamicfeminism

Arsel, İ. (1989). Şeriat ve Kadın, 4. bask1, İstanbul: Kaynak Yayinlari.

Bardan, M. (2013). Feminism in Islam: Secular and Religious Convergence. London: Oneworld Publications. E-book edition. 


\section{From Secular Muslim Feminisim to Islamic Feminism(s)}

Badran, M. (2002). "Islamic Feminism: What's in a Name?” Al-Ahram Weekly Online. no.569, 17 - 23 January, http://weekly.ahram.org.eg/2002/569/cu1.htm 4 Ibid, pp. 1

Badran, M. (1995). Feminists, Islam and Nation: Gender and the Making of Modern Egypt. Princeton: Princeton University Press, 1995.

Barlas, A. (2002). Believing Women in Islam: Unreading Patriarchal Interpretations of the Qur'an. Austin: University of Texas Press.

Barlas, A. (2005). “Qur'anic Hermeneutics and Women's Liberation", Keynote speech presented at International Congress on Islamic Feminism, Barcelona, Spain.

Beauvoir, S. D. (1949). Le deuxième sexe I: Les faits et les mythes. Paris: Editions Gallimard.

Bora, A. (2010). Hatırlananlar ve Unutulanlar: İslam Coğrafyasında Modernleşme ve Kadın Hareketleri. Türk Dünyası Sosyal Bilimler Dergisi, 53, 51-66.

Çaha, Ö. (2010). Sivil Kadın: Türkiye'de Kadın ve Sivil Toplum. Savaș Yayınları.

Çaha, Ö. (2011). "The "Islamic Women's" Movement: Transition from the Private Domain to the Public Sphere". Islam and Civilisational Renewal, 3(1), 116.

Chaudhry, A. S. (2013). Domestic violence and the Islamic tradition. OUP Oxford.

Crenshaw, K. (1989). Demarginalizing the intersection of race and sex: A black feminist critique of antidiscrimination doctrine, feminist theory and antiracist politics. u. Chi. Legal f., 139.

Dalaman, Z.B.(2020). Türkiye ve Tunus'ta Feminist Alternatif Medya ve Kadn Hareketi, İstanbul: Milenyum Yayınları.

Dorroll, P. (2016). "Post-Gezi Islamic Theology: Intersectional Islamic Feminism in Turkey". Review of Middle East Studies, 50(2), 157-171.

Driss, N. (2018). Interview. Z.B. Dalaman. Tunisia. 15 January.

Ensler, E. (2000). Eve Ensler Official Web Site: http://www.eveensler.org/

Göle, N. (1996). The Forbidden Modern: Civilization and Veiling. Ann Arbor,„Mich.: University of Michigan Press.

Graham-Brown, S. (2001). "Women's activism in the Middle East: A historical perspective". Women and power in the Middle East, 23-33.

Güç, A. (2008). “İslamcı Feminizm: Müslüman Kadınların Birey Olma Çabaları”. Uludağ Üniversitesi İlabiyat Fakë̈ltesi Dergisi, 17(2), 649-673.

Gürhan, N. (2010). "Toplumsal Cinsiyet ve İslami Feminist Söylem”, Bilim, Ablak ve Sanat Bağlaminda Cağdaş İslam Algilari, Uluslararasi Semposyum, 26-28 Kasim, Samsun (s. 367-383).

Havle Women Associations's Blog (2020). https://havlekadin.wordpress.com/hakkinda/,

Hidayatullah, A. A. (2014). Feminist Edges of the Qur'an. Oxford University Press, USA.

İngün, Ö. (2005). Feminizm ve İslam İlişkisi: ‘İslami Feminizm’ (unpublished Phd thesis), Uludağ Üniversitesi: Bursa.

Kadivar, M. (2006). Freedom of Religion and Belief in Islam. The.

Kandiyoti, D. (1997). Cariyeler, Bacular, Yurttaşlar, Metis Yayınları: İstanbul

Kaya, B. (2018). İslam ve Feminizm - Müslüman kadın olmak ve kadın haklarını savunmak çelişki mi?: https://www.haberpodium.ch/islam-ve-feminizm-musluman-kadin-olmak-ve-kadin-haklarinisavunmak-celiski-mi/

Mir-Hosseini, Z. (1996). 'Women and Politics in Post-Khomeini Iran: Divorce, Veiling and Emerging Feminist Voices', in Haleh Afshar (ed.) Women and Politics in the Third World, London: Routledge; 149-69.

Mir-Hosseini, Z. (2000). Marriage on Trial: Islamic Family Law in Iran and Morocco, London: I.B. Tauris.

Mir-Hosseini, Z. (2006). 'Muslim Women's Quest for Equality: Between Islamic Law and Feminism', Critical Inquiry, 32: 629-45

Moghadam, V. M. (2002). "Islamic Feminism and Its Discontents: Toward A Resolution of The Debate", Signs, 27, 4

Mohamed, Sarah (2017). From Marriage Beds to Legal Prisons: Egypt Lags in Criminalizing Marital Rape, https://www.auccaravan.com/?p=6734.

Mojab, S. (2001). Theorizing the politics of 'Islamic feminism'. Feminist Review, 69(1), 124-146.

Musawah, A. (2020). Webinar on Muslim family Law Reform: Pathways to change. https://www.musawah. org/blog/webinar-muslim-family-law-reform-pathways-to-change/

Musawah Official Website (n.d.) https://www.musawah.org/about/

Recel-Blog Web Site (n.d.) http:// recel-blog.com/

Sancar, S. (2016). Din, Siyaset Ve Kadin: Iran Devrimi. Nika Yayınevi. Ankara.

\section{Border Crossing}


Sanusiou, K. Y. (2020). Between Feminism and Islamic feminist. The Republic. https://republic.com.ng/ february-march-2020/between-feminsim-and-islam-feminist/

Şeriati, A. (1986). Fatima Fatimadır, (Çev.) F. Yalçınkaya, Dünya Yayınları.

Tankut, T. (2019). Interview, Z.B. Dalaman, Istanbul, April 29, 2019

Tohidi, N. (2003). "Islamic Feminism": Perils and Promises." Middle Eastern Women on the move.

UN Beijing Full Report. (1996). Report of the Fourth World Conference on Women Beijing, 4-15 September 1995. https://www.un.org/womenwatch/daw/beijing/pdf/Beijing\%20full\%20report\%20E.pdf

UN Convention (2006).UN Convention (CEDAW) - Summary. https://www.coe.int/en/web/gendermatters/convention-on-the-elimination-of-all-forms-of-discrimination-against-women-cedaw

VMF - Women and Memory Forum (n.d.). http://www.wmf.org.eg/en/

Wadud, A. (1999). Quran and Woman: Rereading the Sacred Text from a Woman's Perspective. New York: Oxford University Press.

Wadud, A. (2020)."Localization as the Way Towards Islamic Feminism”, Keynote Speech presented at Havle Women's Association Online Conference, December 19-20.

Women's UN Report Network (2006). Second International Congress on Islamic Feminism - Conclusions. https://wunrn.com/2006/11/second-international-congress-on-islamic-feminism-conclusions/

Yamani, M. \& Allen, A. (Eds.). (1996). Feminism and Islam: legal and literary perspectives. NYU Press.

Yüce Tar, Y. (2013). 2000’ler Türkiye'sinde Müslüman Kadının "Kadın Sorunu”, published PhD thesis in Ondokuz Mayıs University, Institute of Social Sciences, Samsun. 